\title{
Maju Mundur Transformasi Aturan Mengenai Analisis Mengenai Dampak Lingkungan Hidup di Indonesia
}

\author{
Ivan Wagner ${ }^{1}$ \\ Universitas Panca Bakti \\ Masuk: 27 November 2020; Diterima: 30 November 2020; Terbit: 30 November 2020.
}

DOI: $10.24905 /$ diktum.v8i2.103

\begin{abstract}
Law Number 11 of 2020 concerning Job Creation has been legally enacted. The government claims that Law Job Creation is to improve the investment climate, especially in the global conditions that are being hit by the Covid-19 pandemic and are predicted to have a correlation with job creation for the peoples. However, from the time the law was proposed, discussed, endorsed, until it was signed, this law has resulted in problems, one of which is about Environmental Impact Assessment (EIA). The research questions formulated are: First, what is the historical trail of the birth and development of the EIA instrument? Second, based on the historical traces of its birth and development, is Law Job Creation a forward movement or is it a backward movement on the discourse of environmental protection? By focusing on the legal history side of EIA, using a socio-legal approach method, it can be conveyed that the traces of regulation on EIA from global discourse to national regulations are actually capable of capturing a value-based transformative vision of environmental awareness and justice. However, the transformation process was mostly carried out by the interests of foreign funding institutions that carried a vision of economic interests that reduced a value-based transformative vision. Law Job Creation is the next milestone in the transformation of regulations regarding EIA and environmental permits. If the vision for the transformation of environmental regulations is about a value-based vision towards a more environmentally aware and environment justice, it is clear that Law Job Creation is like bringing back to the starting point again.
\end{abstract}

Keywords: Job Creation, Environment, Environmental Impact Assessment, Transformation

\footnotetext{
${ }^{1}$ Coresponding author:

Ivan.wagner@upb.ac.id
} 


\begin{abstract}
Abstrak
Undang-Undang Nomor 11 Tahun 2020 tentang Cipta Kerja telah sah diundangkan. Pemerintah mengklaim Undang Undang Cipta Kerja untuk meningkatkan iklim investasi terutama pada kondisi global yang tengah dilanda pandemi covid-19 dan digadang berkorelasi terhadap penciptaan lapangan kerja bagi rakyat. Namun, sejak pengusulan, pembahasan, pengesahan, hingga ditandatangani Undang Undang Cipta Kerja menuai masalah, yang salah satunya mengenai Amdal. Pertanyaan penelitian yang dirumuskan, yaitu: Pertama, bagaimana jejak historis kelahiran dan berkembangnya instrumen Amdal? Kedua, Berdasarkan jejak historis kelahiran dan perkembangannya, apakah Undang Undang Cipta Kerja merupakan gerak maju atau adalah gerak mundur wacana perlindungan lingkungan hidup? Dengan berfokus pada sisi sejarah hukum mengenai Amdal, dengan menggunakan metode pendekatan sosio-legal dapat disampaikan, bahwa jejak pengaturan mengenai Amdal dari diskursus global ke aturan nasional, sebenarnya mampu menangkap visi transformatif berbasiskan nilai yaitu kesadaran dan keadilan lingkungan. Namun, proses transformasi itu lebih banyak dibawa oleh kepentingan lembaga pendanaan asing yang membawa visi kepentingan ekonomi yang mereduksi visi transformatif yang berbasis nilai. Undang-Undang Cipta Kerja menjadi milestone berikutnya dalam transformasi pengaturan mengenai Amdal dan izin lingkungan. Apabila visi transformasi aturan lingkungan hidup ialah mengenai visi berbasis nilai ke arah yang semakin berkesadaran dan berkeadilan lingkungan, tergambar jelas bahwa UU Undang-Undang Cipta Kerja seperti membawa kembali ke titik awal lagi.
\end{abstract}

Kata Kunci: Cipta Kerja, Lingkungan Hidup, Amdal, Transformasi

\title{
A. Pendahuluan
}

Undang-Undang Nomor 11 Tahun 2020 tentang Cipta Kerja (UU 11/2020) telah sah diundangkan pada 2 November 2020 oleh Presiden Joko Widodo. Undang-Undang bertajuk Omnibus Law atau Omnibus Bill yang merupakan proses pembuatan peraturan yang bersifat kompleks dan penyelesaiannya memakan waktu lama karena mengandung banyak materi meskipun subjek, isu, dan programnya tidak selalu terkait ini (Sinclair, 2012). Pemerintah mengklaim UU 11/2020 ialah untuk meningkatkan iklim investasi terutama pada kondisi global yang tengah dilanda pandemi covid-19 dan digadang berkorelasi terhadap penciptaan lapangan kerja bagi rakyat. Namun, sejak pengusulan, pembahasan, pengesahan, hingga ditandatangani presiden Undang Undang Cipta Kerja telah menuai masalah. Bahkan dinilai sebagai pembuatan legislasi terburuk paska reformasi (Komarudin, 2020). Undang Undang Cipta Kerja dinilai tidak hanya bermasalah pada sisi prosedural saja yang berkaitan dengan transparansi dan 
partisipasi publik, namun juga pada sisi substansi, dimana salah satunya dinilai tidak berpihak pada isu perlindungan lingkungan hidup (katadata.co.id, 2020).

Penilaian bahwa Undang Undang Cipta Kerja kontra terhadap perlindungan lingkungan hidup salah satunya terletak pada substansi aturan yang memperlemah instrumen izin lingkungan dan Analisis Mengenai Dampak Lingkungan (Amdal) sehingga Amdal kehilangan banyak "kesaktiannya" (kompas.com, 2020). Sebenarnya wacana pelonggaran terhadap aturan mengenai izin lingkungan dan Amdal telah dihembuskan setidaknya sejak setahun pemerintahan Presiden Joko Widodo yaitu pada tahun 2015. Saat itu, Badan Koordinasi bersama Kementerian Pekerjaan Umum dan Perumahan Rakyat mengusulkan wacana penghapusan Amdal sebagai upaya penyederhanaan izin mendirikan bangunan (IMB) (Apriando, 2015).

Pada 2016, Gubernur DKI Jakarta juga meramaikan wacana penghapusan Amdal, dimana dia menyampaikan isi diskusinya dengan Presiden Joko Widodo mengenai kesamaan Amdal dengan Hinderordonanntie (HO) atau izin gangguan yang dibuat pada zaman kolonial. Gubernur DKI Jakarta melakukan framing bahwa izin Amdal itu sama saja seperti $\mathrm{HO}$ era penjajahan, dimana beliau menyatakan "padahal aturan itu dulu dibikin penjajah untuk menyusahkan rakyat" (detiknews, 2016).

Pada 2018 terbit Peraturan Pemerintah Nomor 24 Tahun 2018 tentang Pelayanan Perizinan Berusaha Terintegrasi Secara Elektronik (PP 24/2018), yang dinilai sebagai pelemahan terhadap Amdal secara konkrit. Hariadi Kartodihardjo dalam wawancara oleh hukumonline.com menyebut bahwa PP 24/2018 itu justru membuat posisi Amdal menjadi tidak strategis dan membuat keberadaan Amdal tidak mempengaruhi apapun terhadap proyek kecuali sekedar mitigasi terkait dampak yang harus ditangani (hukumonline.com, 2019). 
Dalam pemerintahannya, Presiden Joko Widodo memasukkan program penyederhanaan perizinan dan reformasi birokrasi ke dalam programprogramnya, terutama dalam hal paket kebijakan untuk ekonomi. Pada 2019, dalam pidato pelantikan periode kedua kepemimpinannya, Presiden Joko Widodo menyampaikan wacana Omnibus Law yang paska itu secara cepat diusulkan melalui Rancangan Undang-Undang (RUU) Cipta Lapangan Kerja (kemudian berganti nama menjadi Cipta Kerja). RUU ini mendapat pengesahan pada November 2020 dengan berisi 1187 halaman yang terdiri dari 11 kluster, dan merubah substansi setidaknya di 79 Undang-Undang, salah satunya Undang-Undang Nomor 32 Tahun 2009 tentang Perlindungan dan Pengelolaan Lingkungan Hidup (UU 32/2009). Perubahan signifikan ialah mengenai Izin Lingkungan yang didegradasi menjadi persetujuan lingkungan serta berkaitan dengan Amdal yang dilonggarkan.

Persoalan diatas dirasa masih perlu untuk mempertanyakan terutama mengenai instrumen Amdal. Dari sana, ditarik suatu permasalahan untuk diteliti mengenai, bagaimana jejak historis kelahiran dan berkembangnya instrumen Amdal dan apakah Undang Undang Cipta Kerja merupakan gerak maju atau adalah gerak mundur wacana perlindungan lingkungan hidup?

\section{B. Metode Penelitian}

Penelitian yang dilakukan akan berfokus pada sisi sejarah hukum mengenai Amdal, dengan menggunakan metode pendekatan socio-legal. Penelitian sosio-legal pada dasarnya memayungi segala pendekatan terhadap hukum, proses hukum, maupun sistem hukum (Wiratraman, 2008). Pada dasarnya pemikiran sosio-legal menambahkan (perspektif yang lain) dalam mempertimbangkan proses pembentukan legislasi, penerapan hukum dan penyelesaian sengketa (Irianto, et al., 2012). Keberadaan hukum senantiasa memiliki konteks-konteks sosial, ekonomi dan politiknya, dalam ruang sejarah 
tersendiri yang menunjukkan situasi dinamis dalam proses dan perkembangannya. Sosio-legal sebagai konsep perkawinan antara pendekatan dalam ilmu-ilmu hukum dan ilmu-ilmu sosial, telah memiliki tradisi yang panjang, yang telah pula dikembangkan dan tumbuh di fakultas fakultas hukum (Banakar \& Travers, 2005) (Wiratraman, 2008).

Dari pendekatan tersebut, penelitian ini menggunakan data sekunder yang berasal dari hasil penelusuran kepustakaan yang dilakukan. Dari sana akan disajikan pembahasan yang bersifat deskriptif-analitis untuk menampilkan sejarah Amdal dan transformasinya dalam hukum di Indonesia. Selanjutnya, akan diberikan analisis mengenai Undang Undang Cipta Kerja khususnya mengenai Amdal yang dilihat dari konteks kesejarahan yang telah dibahas sebelumnya.

\section{Hasil Penelitian dan Pembahasan}

1. Menghadirkan Amdal dari Diskursus Global ke Pengaturan Nasional dan Transformasi Pengaturan Lingkungan Hidup di Indonesia

Pengertian umum, konsepsi, bahkan keterposisian Amdal sebagai sebuah instrumen pencegahan, pada dasarnya memiliki korelasi dengan transformasi dan perkembangan diskursus tentang lingkungan di tingkat politik global. Selain itu, arus perkembangan demokrasi di Indonesia paska reformasi, juga menandai arah perkembangan konseptual tentang perlindungan dan pengelolaan lingkungan hidup.

Pengertian Amdal telah mengalami perubahan-perubahan sejak pertama kali dilahirkan dalam aturan normatif lewat Undang-Undang Nomor 4 Tahun 1982 tentang Ketentuan-Ketentuan Pokok Pengelolaan Lingkungan Hidup (UU 4/1982). Namun, disamping pengertian dalam hukum tertulis, banyak ahli juga mengkonsepsikan pengertian Amdal. Selain berkaitan dengan suatu bentuk instrumen dan kegiatan studi yang 
di dalamnya berkaitan dengan pekerjaan seperti identifikasi, prediksi, dan interpretasi, Robert Edward Munn menyampaikan bahwa Amdal berkaitan pula dengan kegiatan mengkomunikasikan pengaruh suatu rencana kegiatan itu pada lingkungan (Munn, 2008). Sedangkan Wandesforde-Smith melihat Amdal tidak sebatas aktivitas kajian sebagai syarat kebijakan, melainkan memberi penekanan mengenai "tindakan sadar dan sistematis" yang dikaitkan dengan "konsekuensi lingkungan" (Wandesforde-Smith, 1990). Kita bisa melihat dari Munn, bahwa komunikasi pada lingkungan bisa dibaca bahwa lingkungan seolah merupakan subyek yang memiliki kesadaran, sedangkan dari Wandesforde-Smith, juga menekankan secara definitif bahwa Amdal berkaitan dengan tindakan yang berkaitan dengan kesadaran.

Melacak kelahiran Amdal, tentu saja berbicara mengenai Amerika Serikat dan aksi performatis yang berkaitan dengan kesadaran lingkungan pada akhir tahun 1960an hingga awal tahun 1970an. Amerika Serikat adalah negara yang pertama kalinya memperkenalkan "penilaian lingkungan" (environmental assessment) dan "pernyataan dampak lingkungan" (environmental impact statments) sebagai salah satu instrumen penting dalam pengendalian dampak lingkungan. Hal ini tertuang dalam The National Environmental Policy Act" (NEPA) sebagai aturan pengelolaan lingkungan hidup pertama di dunia (Silalahi \& Kristianto, 2015).

Sebelum terbitnya NEPA, yang mana untuk pertama kalinya mengakomodir kententuan tentang "penilaian lingkungan", pada 13 Juli 1965, Ecological Research and Surveys Bill (RUU Penelitian dan Survei Ekologi) diperkenalkan ke Kongres AS oleh Senator Gaylord Nelson dari Wisconsin dengan tujuan memandu pengambilan keputusan lingkungan melalui informasi dan penyelidikan ilmiah. Secara khusus ia berusaha 
memasukkan prinsip-prinsip ekologis ke dalam kebijakan publik. Akan tetapi, proposal tersebut gagal karena tidak diterima Kongres (Caldwell L. K., 1988). Paska itu, gerakan lingkungan terus membesar dimana Gaylord Nelson merupakan salah satu tokohnya. Pada 1969 Senator Henry M. Jackson dan perwakilan John Dingell memperkenalkan RUU (Bills) dan dibahas dalam Kongres yang kemudian menjadi cikal bakal NEPA. Pada 1 Januari 1970, Presiden Richard Nixon menandatangani NEPA, yang salah satunya mengatur mengenai instrumen pemaksaan tindakan berupa "pernyataan terperinci" tentang dampak lingkungan (Luther, 2005).

Pada dasarnya, kelahiran Amdal dilatarbelakangi oleh tekanan publik, untuk merubah cara pandang terhadap alam dan untuk menggugah kesadaran lingkungan. Terdapat pertalian yang erat, antara upaya untuk memahami dan mengkomunikasikan dampak dari suatu kegiatan terhadap lingkungan, dengan upaya sadar dan sistematis. Bahkan, pada awal konsepsinya Amdal, berkaitan pula dengan dorongan kesadaran, bahwa lingkungan adalah bagian penting dari kehidupan.

Amdal kemudian berkembang dalam diskursus lingkungan di kancah global. Terselenggaranya Konferensi Tingkat Tinggi (KTT) membahas lingkungan dan manusia pada 1972 di Stockholm (Swedia), turut meramaikan dan mengembangkan pembahasan konsepsi-konsepsi mengenai Amdal. Setelahnya, konsepsi mengenai Amdal terus meluas dan mengalami perubahan-perubahan. Lynton K. Caldwel yang dikenal sebagai arsitek dibalik NEPA dan Amdal, menyatakan yaitu : "EIA is now a world-wide phenomenon, and had it not been initiated in the United States, it surely would have been invented somewhere else" (Caldwell L. K., 1988). Hal tersebut akibat faktor determinan utama yaitu gerakan pro lingkungan 
yang terus menyebar ke seluruh dunia dan berkaitan dengan fenomena krisis akibat industrialisasi paska perang dunia kedua.

Konsep penilaian lingkungan (environmental assessment) dan pernyataan dampak lingkungan (EIS) mengalami berbagai penyempurnaan konsep dan metodenya, dan dewasa ini dikenal sebagai Environmental Impact Assessment atau Environmental Impact Analysis (EIA). Di Indonesia, konsep EIA diterjemahkan menjadi Analisis Mengenai Dampak Lingkungan (Amdal). Kelahiran konsep Amdal untuk pertama kalinya tidak terlepaskan dari NEPA. Sementara NEPA adalah jawaban politis dalam rupa instrumen hukum untuk menjawab tekanan publik di Amerika Serikat. Di Indonesia, secara normatif Amdal di-internalisasi pertama kali dalam Undang-Undang Nomor 4 Tahun 1982 tentang KetentuanKetentuan Pokok Pengelolaan Lingkungan Hidup (UU 4/1982).

KTT Stockholm memengaruhi arah pengaturan dan kebijakan mengenai pembangunan dan lingkungan hidup internasional dan termasuk di Indonesia. Munadjat Danusaputro bahkan menyampaikan: “Tahun 1979 rasanya memang tahun yang penuh arti bagi pertumbuhan dan perkembangan hukum lingkungan, khususnya bagi Indonesia" (Danusaputro, 1985). Paska KTT Stockholm, pada 1978 dibentuk jabatan menteri nonportofolio yaitu Menteri Negara Pengawasan Pembangunan dan Lingkungan Hidup (Meneg PPLH) yang dijabat Emil Salim, dan tak lama disusun rancangan undang-undang (RUU) lingkungan hidup Dalam Keputusan Menteri Negara Pengawasan Pembangunan dan Lingkungan Hidup No. KEP-006/1979. Akhirnya RUU tersebut diajukan ke Sidang DPR RI pada Januari 1982 dan disahkan menjadi undang-undang pada 11 Maret 1982, yaitu Undang-Undang Nomor 4 Tahun 1982 tentang KetentuanKetentuan Pokok Pengelolaan Lingkungan Hidup (UU 4/1982) (Rangkuti, 2015). 
Walau demikian, sebenarnya Amdal sudah digunakan sebelum berlakunya UU 4/1982, yaitu dalam proyek-proyek yang mendapatkan bantuan dana dari negara asing atau badan pendanaan internasional yang mengharuskan dilakukannya Amdal sebagai syarat untuk mendapatkan bantuan terebut. Dick dan Bailey mengklaim bahwa Amdal pertama kali digunakan di Indonesia pada tahun 1974 "untuk pembangunan pabrik semen" (Dick \& Bailey, 1992). Sementara Soemarwoto menyampaikan bahwa Amdal telah digunakan untuk proyek Bendungan Saguling di Jawa Barat pada tahun 1979-1980 sebagai syarat dari Bank Dunia untuk mendapatkan pinjaman (Soemarwoto, 2003). Tercatat bahwa lebih dari 10 Amdal telah dilaksanakan sebelum tahun 1980 (Soeratmo, 1988). Hal tersebut juga senada dengan fakta yang disampaikan oleh Organization for Economic Cooperation and Development (OECD), bahwa paska KTT Stockholm, para pemberi pinjaman multilateral dan bilateral memasukkan persyaratan Amdal dalam kriteria kelayakan proyek mereka (OECD, 1996).

Disamping dinamika hukum internasional, ternyata Amdal sebagai syarat bagi cairnya pendanaan proyek-proyek nasional, telah menjadi salah satu faktor determinan diadopsinya Amdal dalam pengaturan nasional. Hal demikian sesuai pula dengan pendapat Sutrisno yang menyampaikan bahwa: situasi politik hukum global mempengaruhi, karena Pemerintah Indonesia sedang giat-giatnya menawarkan investasi penanaman modal bagi investor asing (Sutrisno). Bahkan apabila dilihat dalam peraturan Amdal di Indonesia, semisal tentang tahap penentuan wajib Amdal, wajib UKL-UPL atau cukup SPPL, atau yang sering disebut sebagai preliminary assessment, screening atau penilaian pendahuluan tampak menduplikasi konsep The Environmental Classification System yang merupakan konsep World Bank. Dalam klasifikasi World Bank tersebut, 
untuk kategori B disebut juga sebagai analisis lingkungan parsial (partial environmental assessment/analysis atau partial environmental impact management and monitoring plan) yang dalam hal ini adalah UKL-UPL, sedangkan untuk kategori C ialah SPPL (World Bank, 1997) (Goldberg, 1995).

Clive Briffett menyampaikan bahwa studi lingkungan di negaranegara timur asia (Indonesia termasuk dalam kajiannya) dipengaruhi oleh lembaga luar daripada yang ingin diakui oleh pemerintah negara itu sendiri (Briffett, 1999). Sementara Judith Petts menyampaikan, bahwa Amdal mengalami "Diffusion and Internasionalization" ke berbagai negara. Petts menyampaikan, mekanisme kontrol bervariasi, misalnya proses kontrol yudisial di Amerika Utara, pendekatan pengambilan keputusan dengan kebijaksanaan dan negosiasi seperti di Inggris, dan pendekatan evaluatif contohnya di Belanda, Kanada, Indonesia dan Polandia, yaitu : "based on independent commissions which scope and then review the EIA, support clearly stated decision-making hierarchies" (Petts, 1999). Komisi Independen tersebut ialah Badan Pengendalian Dampak Lingkungan (Bapedal) yang didirikan pada 1990.

Heroepoetri mencatat bahwa masalah mengenai komisi Amdal tersebut dimana ketua komisi masih saja dijabat rangkap oleh pejabat yang duduk dalam pemerintahan sehingga Amdal ditafsirkan sebatas prosedural administratif belaka (Heroepoetri, 1995). Briffet sendiri menggambarkan kelembagaan Bapedal sebagai "hampered and frustrated efforts." (Briffett, 1999). Sedangkan Dadang Purnama menyoroti bahwa partisipasi publik masih sangat lemah dimana publik hanya memiliki kesempatan menyampaikan keprihatinan mereka kepada komisi yang hampir tidak memiliki tanggung jawab mewakili kepentingan publik 
(Purnama, 2003). Naoyuki Sakumoto pun menyebut, bahwa periode UU 4/1982 kacau dan tidak sistematis. Sistem hukum pada saat ini secara keseluruhan merupakan campuran warisan kolonial dengan beberapa undang-undang yang ditandai sebagai terlalu berorientasi pada pembangunan dan/atau otoriter secara politis. Sulit untuk menggambarkan sistem hukum Indonesia sebagai terintegrasi, modern, atau di-demokratisasi pada saat ini (Sakumoto, 2007).

Awal kemunculan konsep Amdal di Indonesia telah bergeser dari fenomena kelahirannya di Amerika Serikat. Pergeseran itu, ialah dari kebutuhan berupa tindakan paksa kepada proyek maupun legislasi agar dapat mengontrol kebijakan yang menyebabkan dampak lingkungan dan tuntutan publik tentang kesadaran lingkungan, berubah menjadi upaya penyeragaman konsep berupa tindakan paksa oleh pemberi pinjaman atau organisasi internasional untuk membiayai proyek-proyek nasional.

Dinamika selanjutnya ialah KTT Bumi tahun 1992 di Rio De Jeneiro (Brazil), yang mengkonsepkan pembangunan yang berkelanjutan (sustainable development). United Nations Conference on Environment and Development (UNCED), dalam deklarasi Rio kemudian mengarahkan instrumentasi Amdal. UU 4/1982 dirasa tidak relevan lagi dengan perangkat hukum internasional maupun kesadaran masyarakat serta perkembangan global (Hardjasoemantri \& Supriyono, 2014), pada tahun 1997 terbitlah Undang-Undang Nomor 23 Tahun 1997 Tentang Pengelolaan Lingkungan Hidup (UU 23/1997) yang menggantikan UU 4/1982 .

Politik hukum UU 23/1997 lebih memperkuat instrumen pembangunan berkelanjutan (Akib, 2015) yang merupakan diskursus global dalam KTT Rio. Sakumoto menyebut dua faktor terbitnya aturan ini, yaitu "one is international impacts and the other is the growing domestic concern 
against emergent environmental problems" (Sakumoto, 2007). Sedangkan S.K. Wadel menyebut, UU 23/1997 terkait dengan dana \$US 4,200,000 dari Bank Dunia (Waddell, 2004). Paska itu, krisis moneter mendera Indonesia dan pergolakan politik memaksa Soeharto mengundurkan diri dari jabatannya sebagai Presiden.

Peraturan pelaksana untuk Amdal terhadap ketentuan UU 23/1997 ialah lewat Peraturan Pemerintah Nomor 27 Tahun 1999 (PP 27/1999) yang ditandatangani oleh Presiden B. J. Habibie, dan diharapkan memberikan keadaan yang lebih demokratis paska runtuhnya rezim orde baru. Periode ini ditandai dengan penetapan 10 pedoman yang ditetapkan Meneg LH dan Kepala BAPEDAL pada tahun 2000, dan pembatalan Komisi Amdal di departemen sektoral di tingkat pusat, sementara tugas penilaian Amdal diberikan kepada Komisi Amdal di Bapedal. Administrasi Amdal juga dibentuk di pemerintahan provinsi dan kabupaten dalam Bapedal-nya. Tanggung jawab untuk menerapkan dan mengawasi Amdal didistribusikan ke semua provinsi dan kabupaten dan dilakukan oleh Bapedal di tingkat nasional, provinsi atau kabupaten. Pengaturan ini diharapkan untuk mempromosikan koordinasi yang lebih jelas dan lebih terintegrasi di bawah satu kepemimpinan lembaga yang kompeten (Purnama, 2003). Dilihat dari Keputusan Kepala Bapedal Nomor 08 Tahun 2000, partisipasi publik juga mengalami perbaikan yang cukup signifikan.

Akan tetapi, terjadi tumpang tindih antara tiga dokumen kebijakan utama tentang pengembangan hukum lingkungan yaitu Ketetapan MPR Nomor IV/MPR/1999 tentang GBHN tahun 1999-2004 (era Habibie), Undang-Undang Nomor 25 Tahun 2000 Tentang Program Pembangunan Nasional (PROPENAS) Tahun 2000-2004 (era Abdurrahman Wahid), dan Undang-Undang Nomor 17 Tahun 2007 Tentang Rencana Pembangunan 
Jangka Panjang Nasional Tahun 2005-2025 (era Megawati dan Susilo Bambang Yudhoyono) (Sakumoto, 2007).

Otto Soemarwoto bahkan menghardik secara keras bahwa terdapat dualisme antara Repelita/Propenas/Propeda dengan Agenda 21 maupun dualisme pembagian tugas antara Menteri/Ketua Bappenas dengan Meneg LH (Soemarwoto, Dualisme Propenas dan Agenda 21 , 2003). Dari sisi institusi ketatanegaraan, bahkan terjadi pengalihan fungsi dan kewenangan Bapedal ke Meneg LH pada tahun 2002 melalui Keputusan Presiden Nomor 2 Tahun 2002 Tentang Perubahan Atas Keputusan Presiden Nomor 101 Tahun 2001 Tentang Kedudukan, Tugas, Fungsi, Kewenangan, Susunan Organisasi, Dan Tata Kerja Menteri Negara. Hal ini dinilai oleh Organisasi Non-Pemerintahan (ORNOP) Lingkungan Hidup seperti WALHI sebagai sebuah kemunduran (set back), (sebagai) upaya mereduksi fungsi Bapedal, (menjadi) tragedi lingkungan hidup, bahkan disebut sebagai munculnya rezim baru tanpa agenda lingkungan hidup (Emmy Hafild (Walhi), 2003). Bapedal yang semula menjadi lembaga yang langsung berada dibawah Presiden sering berkonfrontasi dengan kementerian yang juga berada dibawah Presiden, kelembagaan Bapedal kemudian dilebur kedalam kelembagaan Meneg LH.

Pada periode berlakunya UU 23/1997, aturan mengenai Amdal kembali terjerumus pada penyakit programatisnya, yaitu persepsi yang keliru, dan hanya dipandang sebagai persyaratan formalitas untuk mendapatkan izin usaha dan/atau kegiatan. Kekeliruan persepsi ini mengakibatkan rendahnya kualitas dokumen Amdal (DPR RI, 2009). Dari analisis dalam risalah pembahasan RUU tentang Pengelolaan Lingkungan Hidup yang kemudian melahirkan UU 32/2009 menggantikan UU 23/1997, sebenarnya membawa angin segar bagi pembenahan aturan mengenai 
Amdal, bahwa dilihat dalam Risalah Sidang pembahasan RUU Pengelolaan Lingkungan Hidup tahun 2009 dapat diidentifikasi dua isu besar Amdal yang hendak dijawab, yaitu mengenai kualitas Amdal dan kualitas penilaian atau pengambilan keputusannya agar tidak dimasuki unsur politik atau kepentingan pejabat publik dan aktor kapital. Akan tetapi, dua isu itu justru berujung pada generalisasi yang tidak koheren dengan maksud awalnya, yaitu generalisasi pada sanksi pidana dan rekrutmen yang baik dimana tidak menjawab kedua permasalahan (Wagner \& Suteki, 2019).

Kritik Amdal dalam UU 32/2009 dapat dibagi setidaknya dalam dua isu besar, yaitu konsep dan berkaitan dengan rumusan kewenangan disekitar aturan Amdal. Pada konsep Amdal, tiga kritik utama yaitu: pertama, independensi penilaian Amdal cenderung naif pada relasi kuasa yang ciptakan oleh instrumen lainnya (misal KLHS, Penataan Ruang, Rencana Pembangunan, dll). Meminjam pendapat Tim Richardson, bahwa prosedur pengambilan keputusan seperti perencanaan penggunaan lahan dan alat pengambilan keputusan, seperti Amdal, tidak lebih dari sekadar tabir di balik keputusan yang dilegitimasi sedemikian rupa (Richardson, 2005). Rencana-rencana pembangunan yang juga merupakan produk hukum politis, sedari awal telah mengarahkan agar Amdal cenderung layak dibandingkan tidak layak. Dari sana, kecenderungan Amdal kembali ke penyakit bawaannya yang bersifat prosedural administratif tidak dapat dihindari.

Kedua, asumsi bahwa Amdal menolak kepentingan politis ialah utopis, karena relasi kuasa yang tercipta merupakan bias yang bersifat struktural (structural bias) yang sulit dihindari, terutama berkaitan dengan ambisi politik pembangunan kepala pemerintahan. Ketiga, bahwa konsep 
Amdal sendiri, seperti pembahasan historisnya ialah diskursus global yang bersifat determinatif, top-down, dan cenderung digunakan sebagai instrumen bagi akumulasi kapital. Sementara dari sisi kewenangan, kritik di alamatkan pada konsep kewenangan yang mengakomodir kewenangan bagi pemerintah daerah, namun dibalik tabirnya sebenarnya hanya merupakan sentralisasi dan dominasi bagi kewenangan eksekutif, tidak hanya bagi pengoperasionalisasian Amdal (penilaian dan penerbitan izin), namun juga meliputi perencanaan pembangunan (RPJM/RKP), pengalokasian ruang (RTRW, inisiatif eksekutif), hingga pada taraf kajian lingkungan hidup strategis (KLHS) yang akan menjadi batu uji normatif bagi Amdal dan Izin.

Tidak mengherankan, semisal persoalan kualitas dan efisiensi Amdal terus mengulang persoalan yang sama, yaitu seperti yang diungkapkan Hariadi Kartodihardjo, bahwa niat membuat Amdal lebih untuk memenuhi syarat administrasi izin, bukan untuk melindungi lingkungan atau menghindari konflik (Kartodihardjo, 2017). Pada kesempatan yang sama, Eko Teguh Paripurno menyatakan bahwa penyebab buruknya produk Amdal juga disebabkan Komisi Penilai Amdal yang lebih sering berpihak pada investor daripada masyarakat dan lingkungan (Paripurno, 2017). Hal tersebut kemudian memunculkan potensi korupsi yang besar, dampak destruktif kepada alam, serta konflik sosial yang tak berkesudahan. Semuanya itu, difasilitasi oleh aturan hukum yang tidak mumpuni dalam mentransformasikan kesadaran dan keadilan lingkungan.

Dari jejak pengaturan mengenai Amdal dari diskursus global ke aturan nasional, sebenarnya mampu menangkap visi transformatif berbasiskan nilai yaitu kesadaran dan keadilan lingkungan yang 
dicetuskan sejak kelahiran Amdal di Amerika Serikat. Hal sesuai dengan yang disampaikan oleh Otto Soemarwoto yang menyampaikan bahwa:

Amdal lahir dengan tujuan untuk menghindari terjadinya kerusakan lingkungan oleh kegiatan manusia, dan Amdal lahir untuk mengatasi masalah itu. Sementara itu kesadaran lingkungan makin meningkat. Kesadaran itu sebagian tumbuh dari hati nurani yang tulus, sebagian lagi karena terpaksa oleh adanya perundang-undangan lingkungan maupun oleh adanya kritik dari masyarakat (Soemarwoto, 2003).

Namun, proses transformasi Amdal dari global ke hukum nasional lebih banyak dibawa oleh kepentingan lembaga pendanaan asing yang membawa visi kepentingan ekonomi yang mereduksi visi transformatif yang berbasis nilai. Paska reformasi, pembenahan telah dilakukan hingga kelahiran UU 32/2009. Namun, harus diakui bahwa pembenahan itu masih meninggalkan segudang masalah laten berkaitan dengan konsep Amdal serta kewenangan berkaitan dengan Amdal.

\section{Membaca Arah Gerak Transformasi Pengaturan Amdal di Indonesia}

UU 11/2020 tentang Cipta Kerja telah disahkan, dimana substansinya menjadi milestone berikutnya dalam transformasi pengaturan mengenai lingkungan hidup, khususnya mengenai Amdal dan izin lingkungan. Dalam operasionalisasinya, aturan mengenai Amdal dan perizinan dalam UU 11/2020 masih menunggu aturan pelaksananya berupa peraturan pemerintah. Sejak 17 November 2020, melalui portal uu-ciptakerja.go.id, Rancangan Peraturan Pemerintah (RPP) Bidang Perlindungan dan Pengelolaan Lingkungan Hidup (PPLH) sudah dipublikasi ke publik.

Dari UU 11/2020 maupun RPP Bidang PPLH kita dapat mencermati, bahwa visi dari Amdal sejak kelahirannya di Amerika Serikat yaitu berkaitan dengan kesadaran lingkungan global dan instrumentasi kepentingan publik telah ditempatkan secara marjinal ketimbang 
pemikiran akumulasi dan kepentingan ekonomi. Hal yang tersisa dari efek transformatif Amdal dari diskursus global ke aturan nasional sejak 1982 hanyalah kepentingan dibaliknya, hal itu terutama dapat dilihat dari penggunaan satu-satunya indikator yang digunakan sebagai basis justifikasi untuk penyederhanaan izin dan pelonggaran regulasi (deregulasi) yaitu tabel peringkat bersifat kuantitatif dari Ease of Doing Bussiness (EODB) dari World Bank.

Sementara isu-isu krusial secara kualitatif berkaitan dengan pengaturan Amdal sejak mendarat dan bercengkrama dengan lingkungan maupun masyarakat Indonesia, antara lain: pertama, masalah demokratisasi, partisipasi publik, dan keterbukaan informasi. Kedua, kualitas Amdal. ketiga, persoalan kewenangan, dan kelembagaan mengenai penilaian Amdal. keempat, pengawasan dan penegakan hukum, justru menjadi bagian yang mengalami deregulasi bahkan penghapusan.

Masalah demokratisasi, partisipasi publik, dan keterbukaan informasi, aturan Amdal dalam UU 11/2020 seperti mengulang periode UU 4/1982 yang berisikan keluhan mengenai partisipasi publik yang minim dan kaitannya dengan rezim pemerintahan sentralistik dan otoriter. Masalah kualitas Amdal, seperti mengulang periode-periode sebelumnya, Amdal akan semakin ditempatkan sekedar syarat bagi pembangunan. Terlebih lagi, indikator-indikator esensial dalam kriteria usaha berdampak penting dimarjinalkan kedalam aturan pelaksana, dan dengan pengujiannya yang dimonopoli oleh pemerintah pusat, serta partisipasi publik yang dipersempit, telah mengantarkan konsep yang demikian pada era dimana Amdal belum lahir, yaitu ketika indikator "boleh atau tidaknya" suatu kegiatan/usaha hanya urusan penguasa belaka. 
Persoalan kewenangan, dan kelembagaan mengenai penilaian Amdal dalam UU 11/2020 dapat dinilai seperti pernyataan Walhi pada saat peleburan Bapedal pada 2003 serta kritik Heroepoetri pada tahun 1995, dimana penilaian Amdal tidak bersifat peninjauan ilmiah (scientific review) dan tidak berdasarkan suara publik (public review), melainkan bersifat peninjauan oleh para birokrat (bureaucratic review). Sedangkan mengenai pengawasan dan penegakan hukum, seutuhnya tersentral pada pemerintah pusat. Hal ini menghapus kewenangan daerah, menghapus pejabat pengawas lingkungan hidup, dan menghapus kewenangan menteri lingkungan hidup dan kehutanan (LHK) untuk melakukan pengawasan lapis kedua (oversight) (ICEL, 2020). Belum lagi mengenai peleburan izin lingkungan (yang melegitimasi Amdal) dalam perizinan berusaha, sehingga gugatan terhadap izin lingkungan, dengan Amdal sebagai batu ujinya menjadi hilang. Hal ini jelas seperti set back ke periode UU 4/1982 dimana pengawasan dan penegakan hukum mengenai kewajiban Amdal sama sekali tidak berarti.

Dari pembahasan diatas, jelas tergambar bahwa transformasi aturan lingkungan hidup dalam UU 11/2020, khususnya mengenai visi Amdal ke arah yang semakin berkesadaran dan berkeadilan lingkungan seperti kembali ke titik awal lagi. Ditengah kondisi global yang makin berkesadaran lingkungan terutama soal perubahan iklim, yaitu dengan mengencangkan sabuk pengaman sembari menata pertumbuhan ekonomi, Indonesia justru seperti berkendara secara ugal-ugalan dengan sabuk pengaman yang semakin longgar.

Kita perlu mengulang sekali lagi visi itu sebagaimana disampaikan oleh pencetus Amdal yaitu Lynton Caldwell, yang menyampaikan: 
Mengekang egoisme atau keserakahan individu pada akhirnya hanya dimungkinkan melalui diberlakukannya hukum yang mengikat. Ini seperti harus memakai sabuk pengaman. Orang-orang pada awalnya tidak menyukai pembatasan seperti itu sebagai hal yang merusak "kebebasan" yang mereka rasakan, tetapi sebagian besar akan mengikuti mereka begitu mereka menyadari bahwa tujuan mereka adalah untuk memberikan keamanan yang lebih besar (Caldwell L. , 2003)

Dari Caldwell tersebut, terdapat relasi antara kegiatan, usaha atau kebijakan, dengan dampak lingkungan, hukum positif, dan dengan "kebebasan". Menariknya, Caldwell menyatakan mengenai "pengekangan" dengan "kebebasan" yang pada dasarnya berkontradiksi, hal tersebut kemudian berlanjut kepada ungkapan mengenai kesadaran, yakni untuk membuat semacam "sabuk pengaman" dalam bentuk aturan yang mengikat. Menggunakan hukum sebagai alat transformasi bukan tanpa risiko, yang tampak dalam realitas UU 11/2020. Hal ini sesuai dengan apa yang disampaikan oleh Jennifer Nedelsky, bahwa setiap kali seseorang menggunakan hukum sebagai alat transformasi, ia menanggung risiko yang terkait dengan menggunakan "the master's tools"- karena hukum hampir secara definisi dikendalikan oleh mereka yang memiliki kekuasaan (Nedelsky, 2011). Dari persoalan yang sifatnya prosedural, menuju substansi hukum, kini persoalan bergerak menuju hal yang sifatnya budaya hukum, yaitu egoisme dan keserakahan elit oligarki dan sistem ekonomi berbasis akumulasi (kapitalisme).

\section{Simpulan}

Dari jejak pengaturan mengenai Amdal dari diskursus global ke aturan nasional, sebenarnya mampu menangkap visi transformatif berbasiskan nilai yaitu kesadaran dan keadilan lingkungan yang dicetuskan sejak kelahiran Amdal di Amerika Serikat. Namun, proses transformasi Amdal dari global ke hukum nasional lebih banyak dibawa oleh kepentingan lembaga pendanaan 
asing yang membawa visi kepentingan ekonomi yang mereduksi visi transformatif yang berbasis nilai. Paska reformasi, pembenahan telah dilakukan hingga kelahiran Undang Undang Nomor 32 Tahun 2009 tentang Pengelolaan Perlindungan Lingkungan Hidup. Namun, harus diakui bahwa pembenahan itu masih meninggalkan segudang masalah laten berkaitan dengan konsep Amdal serta kewenangan berkaitan dengan Amdal.

UU 11/2020 tentang Cipta Kerja telah disahkan, dimana substansinya akan menjadi milestone berikutnya dalam transformasi pengaturan mengenai lingkungan hidup, khususnya mengenai Amdal dan izin lingkungan. Apabila visi transformasi aturan lingkungan hidup ialah mengenai visi berbasis nilai ke arah yang semakin berkesadaran dan berkeadilan lingkungan, tergambar jelas bahwa UU 11/2020 seperti membawa kembali ke titik awal lagi. Ditengah kondisi global yang makin berkesadaran lingkungan terutama soal perubahan iklim, yaitu dengan mengencangkan sabuk pengaman sembari menata pertumbuhan ekonomi, Indonesia justru seperti berkendara secara ugal-ugalan dengan sabuk pengaman yang semakin longgar.

\section{Daftar Pustaka}

Akib, M. (2015). Penegakan Hukum Lingkungan dalam Perspektif Holistik-Ekologis. Yogyakarta: Graha Ilmu.

Apriando, T. (2015, Juli 2015). mongabay.co.id. Dipetik November 26, 2020, dari https:/www.mongabay.co.id/2015/07/23/bkpm-usul-hapus-izin-lingkungankala-dirikan-bangunan-apa-kata-mereka/

Banakar, R., \& Travers, M. (2005). Theory and Method in Socio-Legal Research. Oregon and Portland: Hart Publishing.

Briffett, C. (1999). Environmental impact assessment in East Asia. Dalam J. P. (eds), Handbook of environmental impact assessment. Vol. 2. Environmental impact assessment in practice: impact and limitations (hal. 144). Oxford: Blackwell. 
Caldwell, L. (2003). Perspective: An Interview with Lynton Caldwell on the National Environmental Policy Act (NEPA). Environmental Practice, 5(4), 281-286. doi:10.1017/S1466046603031259

Caldwell, L. K. (1988). Environmental Impact Analysis (EIA): Origins, Evolution, and Future Directions. 6(3-4), 75-83. doi:10.1080/07349165.1988.9725648

Craik, N. (2008). The International Law of Environmental Impact Assessment: Process, Substance, and Integration. New York: Cambridge University Press.

Danusaputro, M. (1985). Hukum Lingkungan; Buku II : Nasional. Bandung: Binacipta. detiknews. (2016, Januari 22). news.detik.com. Dipetik November 26, 2020, dari https://news.detik.com/berita/d-3124573/alasan-ahok-ingin-hapus-izin-amdaldi-dki-seperti-aturan-era-penjajahan

Dick, J., \& Bailey, L. (1992). Indonesia's environmental assessment process (AMDAL): progress, problems and a suggested blueprint for improvement. Jakarta: The Environmental Management Development in Indonesia (EMDI) Project.

DPR RI. (2009). Naskah Akademis Rancangan Undang-Undang Pengelolaan Lingkungan. Jakarta: DPR-RI.

Emmy Hafild (Walhi). (2003, Juli 14). Penggabungan Bapedal dengan Meneg LH itu Set Back. Tempo.co. Jakarta. Dipetik November 26, 2020, dari https://nasional.tempo.co/read/544/penggabungan-bapedal-dengan-meneglh-itu-set-back

Goldberg, D. M. (1995). A Comparison of Six Environmental Impact Assessment Regimes. Washington, D.C: Center for International Environmental Law.

Hardjasoemantri, K., \& Supriyono, H. (2014). Hukum Lingkungan. Jakarta: Universitas Terbuka,.

Heroepoetri, A. (1995). Masalah AMDAL Fiktif: Dari PP 29 ke PP 51. II(1), 89-102.

hukumonline.com. (2019, Mei 15). hukumonline.com. Dipetik November 26, 2020, dari https://www.hukumonline.com/berita/baca/lt5cdc18e537f3c/pp-oss-dinilailemahkan-posisiwajib-amdal/

ICEL. (2020). Pelemahan Instrumen Perlindungan dan pengelolaan Lingkungan Hidup dalam RUU Cipta Kerja. Jakarta: Indonesian Center for Environmental Law.

Irianto, S., Otto, J., Pompe, S., Bedneer, A., Vel, J., Stoler , S., \& Arnscheidt, J. (2012). Kajian Sosio-Legal, Seri Unsur-Unsur Penyusun Bangunan Negara Hukum. (T. Moelyono, Penerj.) Jakarta: Universitas Indonesia, Universitas Leiden, Universitas Groningen: Pustaka Harapan. 
Kartodihardjo, H. (2017, September 26). Korupsi Amdal Sumber Kerusakan Lingkungan. Harian Kompas,. Jakarta.

katadata.co.id. (2020, Oktober 6). katadata.co.id. Dipetik November 26, 2020, dari https://katadata.co.id/sortatobing/ekonomi-hijau/5f7c3f0e25cc1/bahaya-pasalpasal-omnibus-law-uu-ciptaker-yang-ancam-lingkungan-hidup

Komarudin, U. (2020, November 10). Polemik UU Omnibus Law Cipta Kerja. Dipetik November 26, 2020, dari akurat.co: https://akurat.co/news/id-1234110-readpolemik-uu-omnibus-law-cipta-kerja

kompas.com. (2020, November 11). nasional.kompas.com. Dipetik November 26, 2020, dari https://nasional.kompas.com/read/2020/11/03/09250841/ini-6-poinperubahan-terkait-amdal-di-uu-cipta-kerja?page=all

Luther, L. (2005). The National Environmnetal Policy Act: Background and Implementation, CRS Report for Congress. Congressional Research Center, The Library of Congress. Dipetik Maret 30, 2019, dari https://www.transit.dot.gov/sites/fta.dot.gov/files/docs/Unit1_01CRSReport.p df

Munn, R. E. (2008). Dalam N. Siahaan, Hukum Lingkungan; Cetakan Kedua Edisi Revisi (hal. 190). Jakarta: Pancaran Alam.

Nedelsky, J. (2011). Law's Relations: A Relational Theory of Self, Autonomy, and Law. Oxford and New York: Oxford University Press.

OECD. (1996). Coherence in Environmental Assessment: Practical Guidance on Development Cooperation Projects. Paris: OECD.

Paripurno, E. T. (2017, September 26). Korupsi Amdal Sumber Kerusakan Lingkungan. Kompas. Jakarta.

Petts, J. (1999). Introduction to Environmental Impact Assessment in Practice: Fulfilled Potential or Wasted Opportunity?, dalam. Dalam J. Petts, Handbook of environmental impact assessment. Vol. 2. Environmental impact assessment in practice: impact and limitations (hal. 3-4). Oxford: Blackwell.

Purnama, D. (2003). Reform of the EIA process in Indonesia: improving the role of public involvement. 23, 415 - 439. doi:10.1016/S0195-9255(03)00046-5

Rangkuti, S. (2015). Hukum Lingkungan Dan Kebijaksanaan Lingkungan Nasional (Edisi Keempat). Surabaya: Airlangga University Press.

Richardson, T. (2005). Environmental assessment and planning theory: four short stories about power, multiple rationality, and ethics. Environmental Impact Assessment Review, 25, 341-365. doi:10.1016/j.eiar.2004.09.006 
Sakumoto, N. (2007). Development Of Environmental Law And Legal Reform In Indonesia dalam Reforming Laws and Institution in Indonesia: An Assessment. Institute of Developing Economies, Japan External Trade Organization (IDE-JETRO.

Silalahi, D., \& Kristianto, P. (2015). Perkembangan Pengaturan AMDAL Di Indonesia. Bandung: CV Keni Media.

Sinclair, B. (2012). Unortodhox Lawmaking: New Legislative Processes in the U.S Congress. Los Angeles: Sage.

Soemarwoto, O. (2003). Analisis Mengenai Dampak Lingkungan (cetakan ke-10). (Yogyakarta: Gadjah Mada University Press.

Soemarwoto, O. (2003). Analisis Mengenai Dampak Lingkungan (cetakan ke-10). Yogyakarta: Gadjah Mada University Press.

Soemarwoto, O. (2003). Dualisme Propenas dan Agenda 21 . Kompas, 5 Juni. Dipetik Juli 2, 2019, dari http://perpustakaan.bappenas.go.id/lontar/file?file=digital/blob/F2725/Dualis me\%20Propenas\%20dan\%20Agenda\%2021.htm

Soeratmo, F. (1988). Analisis mengenai dampak lingkungan (environmental impact analysis). Yogyakarta: Gadjah Mada University Press.

Sutrisno. (2011), Hlm. 453). Politik Hukum Perlindungan dan Pengelolaan Lingkungan Hidup. 3(18 Juli 2011), 453.

Waddell, S. K. (2004). The Role Of The 'Legal Rule' In Indonesian Law: Environmental Law and Reformasi of Water Quality Management. Sydney: University Of Sidney.

Wagner, I., \& Suteki. (2019). Independensi Penilaian Amdal Sebagai Wujud Perlindungan Terhadap Lingkungan Hidup. Jurnal Pembangunan Hukum Indonesia, 1(3), 404. doi:10.14710/jphi.v1i3.404-424

Wandesforde-Smith, G. (1990). Environmental Impact Assessment, Trends in Environmental Policy and Law. Berlin: Erich Schmidt.

Wiratraman, H. P. (2008). Penelitian Sosio-Legal dan Konsekuensi Metodologisnya. Studium Generale, Sekolah Pascasarjana Universitas Airlangga. Surabaya: Center of Human Rights Law Studies (HRLS) Fakultas Hukum Universitas Airlangga.

World Bank. (1997). The Impact of Environmental Assessment: a review of World Bank experience. Washington, D.C: The World Bank,. 